\title{
Soil attributes functionality and water eutrophication in the surrounding area of Itaparica Reservoir, Brazil
}

\author{
José C. de Araújo Filho', Günter Gunkel ${ }^{2}$, Maria C. M. Sobral ${ }^{3}$, \\ Martin Kaupenjohann ${ }^{4} \&$ Helio L. Lopes ${ }^{3}$
}

\begin{abstract}
In semi-arid areas of Brazil, climate and geological conditions are important factors that restrict the availability of soils and water for sustainable irrigated agriculture. The main objective of this study was to evaluate functionalities of physical and chemical attributes of soils and to provide information about irrigation water quality in the margins of the Itaparica Reservoir aiming the sustainable land use. Available data of 44 representative soil profiles comprising 21 profiles of Arenosols, six of Ferralsols, five of Luvisols, six of Planosols and six of Cambisols were used. Water samples along the margins of the reservoir were analysed to obtain information on water quality. The results indicated a narrow relationship between the functionalities of physical and chemical attributes and the parent material of the soils. The low nutrient availability and high water permeability are the typical characteristics of the soils developed on the sandy covers. On the other hand, higher nutrient availability and permeability restrictions are the most important features of the soils with larger influence of fine sediments. The results also suggested the process of water eutrophication in the Itaparica Reservoir.
\end{abstract}

Key words: Jatobá Basin, water pollution, semi-arid

\section{Funcionalidade de atributos do solo e eutroficação das águas nos arredores do Reservatório de Itaparica}

\section{RESUMO}

Na região semiárida do Brasil as condições climáticas e geológicas são os fatores que mais restringem a disponibilidade de solos para agricultura irrigada. O objetivo principal do estudo foi avaliar funcionalidades de atributos físicos e químicos dos solos e gerar informações sobre a qualidade das águas nas margens do reservatório de Itaparica, visando ao uso sustentável das terras. Em função da disponibilidade de informações foram estudados 21 perfis de Neossolos Quartzarênicos, seis de Latossolos, cinco de Luvissolos, seis de Planossolos e seis de Cambissolos. Amostras para avaliação da qualidade das águas foram coletadas ao longo das margens do reservatório. Os resultados indicaram uma estreita relação entre as funcionalidades de atributos físicos e químicos e o material de origem dos solos. A baixa oferta de nutrientes e a alta permeabilidade foram as características típicas dos solos desenvolvidos a partir das coberturas arenosas. Por outro lado, a maior oferta de nutrientes e as maiores restrições de permeabilidade foram as características mais relevantes dos solos originados de materiais com maior influência de sedimentos finos. Os resultados também sugeriram o processo de eutrofização das águas do reservatório de Itaparica.

Palavras-chave: Bacia do Jatobá, poluição de águas, semiárido 


\section{INTRODUCTION}

Itaparica Reservoir is located in the sub-medium basin of the São Francisco River, in the semi-arid region of Northeast Brazil, between the States of Bahia and Pernambuco. The reservoir extends through two great landscape units, the Hinterland Depression and the Jatobá-Tucano Sedimentary Basin. Due to the climate and geological conditions, in the first great landscape unit there is a predominance of shallow and stony soils, whereas in the second unit, deep and sandy soils dominate.

At the reservoir margins, irrigated agriculture practiced by small farmers is the most common activity. There is low availability and great competition for irrigable land without proper land suitability evaluation. As a consequence, soil degradation and other environmental problems, including soil salinization, take place (Corrêa et al., 2010). In this region, irrigation water may be considered as a source of contaminants for the soils, being a linked system by nutrient export from the watershed and contaminant input by agricultural used water. The littoral zone of the reservoir, where water abstraction for irrigation and human consumption occurs, is the most contaminated lake area (CHESF, 2004).

In the Jatobá Basin area, Pernambuco State, about $90 \%$ of the soils surrounding the reservoir were developed in a sand cover. Consequently, these soils are predominantly sandy, but some of them are medium textured. The remaining $10 \%$ of the soils are clayey or very clayey in texture, as a result of the fine sediment parent material (CHESF, 1987; Silva et al., 2007). In the sandy covers located dominantly in the upper parts, at least $60 \%$ of the soils are classified as Arenosols of the World Reference Base for Soil Resources (WRB) classification system (IUSS Working Group WRB, 2007). The other $40 \%$ of the soils are medium textured comprising Ferralsols, Cambisols and Lixisols of the WRB system. The soils developed from fine sediments in the lower areas commonly have a vertic horizon, mainly the Cambisols, Luvisols and Vertisols. In the lower areas where the sandy covers have an interface with fine sediments, Planosols and Luvisols commonly occur. Soils like Fluvisols and Leptosols also are found in the region, but in a very low proportion (CHESF, 1987; Silva et al., 2007).

Soil quality is a function of inherited, relatively stable properties like texture, as well as of other dynamic properties which are influenced by human use and management like organic carbon, nitrogen and phosphorus content (Sahrawat et al., 2010). However, it should be emphasized that in tropical conditions inherited properties are considered more important indicators of soil quality than in the temperate climate zone (Sanchez et al., 2003).

The main objective of this study was to evaluate the functionalities of physical and chemical attributes of representative soils as well as to provide information on water quality regarding mainly eutrophication process aiming to the sustainable land use at the margins of the Itaparica Reservoir.

\section{Material And Methods}

The study area is located in the sub-water basin of Itaparica Reservoir in the Jatobá Basin (Figure 1). The dominant

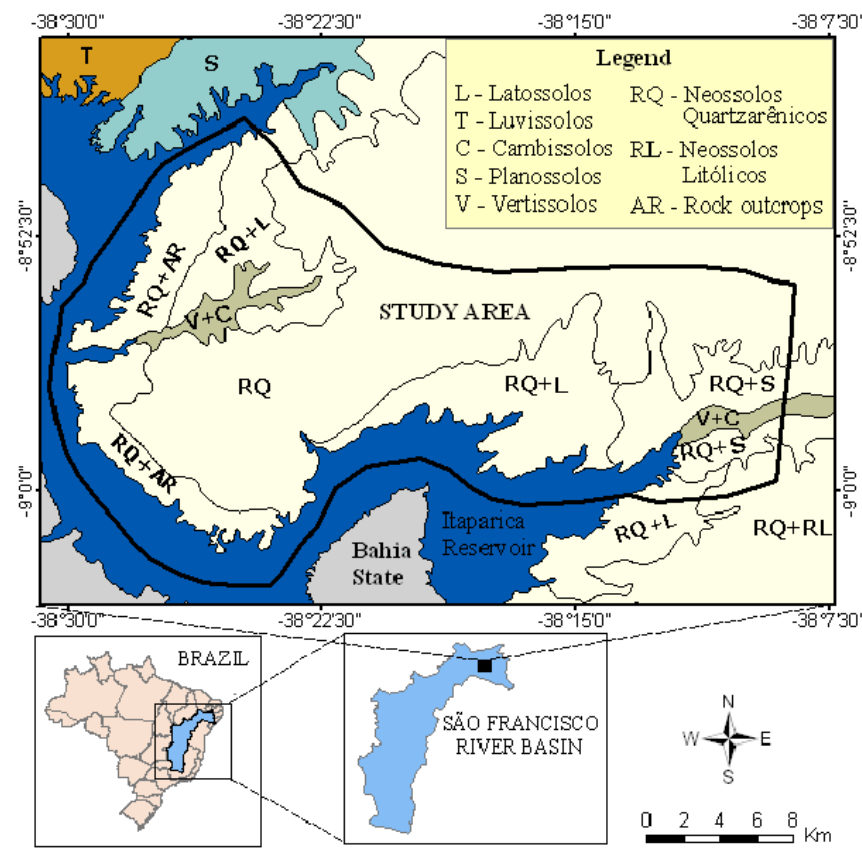

Figura 1. Map of dominant soils at the margins of Itaparica Reservoir showing the study area (adapted from Araújo Filho et al., 2000)

soils belong to the Arenosols class (IUSS Working Group WRB, 2007). In much smaller proportion occur Ferralsols, Lixisols, Cambisols, Luvisols, Planosols, Vertisols, Fluvisols and Leptosols (CHESF, 1987; Silva et al., 2007). As regards geology, the surface of the basin corresponds to an extensive sandy cover of Tertiary/Quaternary age whose pelitic fraction is extremely rare (Figure 2). In smaller and lower areas, the clayey material comprising shales and siltstones, interbedded with fine sandstones, occur. Fine to coarse sandstones can also be found in the area (Rocha \& Leite, 1999). The predominant regional relief is gently undulating with some undulating slopes. As a

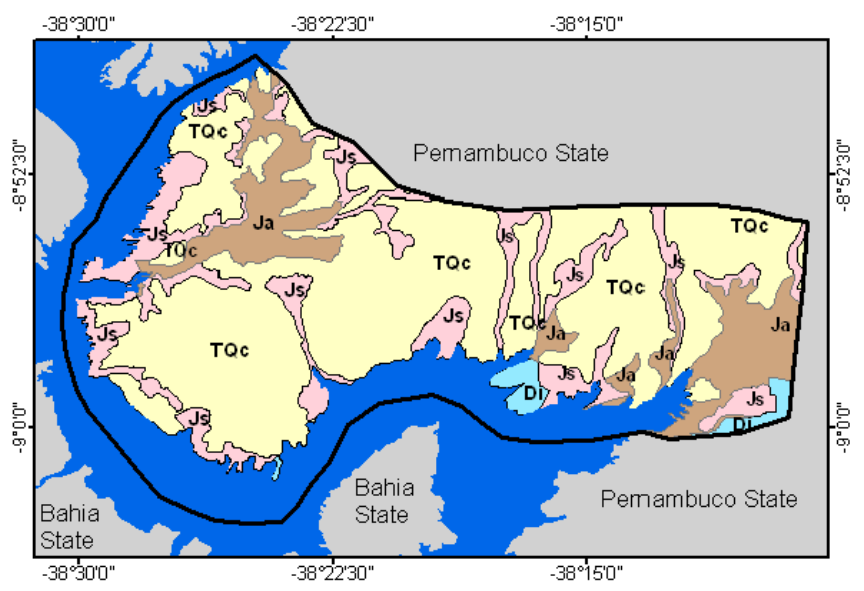

$$
\text { Legend }
$$

$\mathrm{TQc}-$ Sandy covers with rare subordinate pelites (Tertiary/Quaternary). $\mathrm{Js}-\mathrm{Co}$ arse to fine sandstones (Jurassic).

$\mathrm{Ja}$ - Shales and siltstones interbedded with calcareous sandstones and calcareous siltstones (Jurassic).

$\mathrm{Di}-$ Fine to medium sandstones interbedded with shales and siltstones (Devonian)

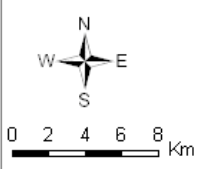

Figura 2. Geological map of Jatobá Basin in the study area (adapted from Rocha \& Leite (1999)) 
consequence of the high permeability of the sandy cover, the drainage network is relatively poor, featuring in the extreme North the Mandantes Creek, and in the Southern center, the Barreiras Creek.

Due to the semi-arid climate with scarce and irregularly distributed rainfall, there occurs a deciduous shrubby and arboreous thorny vegetation, named 'hyperxerophilous caatinga'. The mean annual rainfall is $450 \mathrm{~mm}$ and the potential evapotranspiration is about $1400 \mathrm{~mm}$. The mean annual temperature is about $26{ }^{\circ} \mathrm{C}$ with small variations throughout the year (Brasil, 1973).

Morphological, physical and chemical data of 44 soil profiles were used (Table 1). Those profiles were selected from detailed studies which were carried out before the use of agricultural irrigation in the area (CHESF, 1987). Data of surface horizon A, named topsoil, refer to the $0-20 \mathrm{~cm}$ soil layer, and those of subsurface horizon B and/or C, named subsoil, refer to the soil layer from $20 \mathrm{~cm}$ down to the limit of $150 \mathrm{~cm}$. Soil map information was obtained from previous soil surveys (CHESF, 1987; Silva et al., 2007). Soil analysis of selected profiles were performed according to methods of EMBRAPA (1997).

Analytical soil parameters selected for this study were silt and clay content, available water capacity (AWC), water infiltration capacity (I), electrical conductivity (EC), $\mathrm{pH}$, sum of the bases $(\mathrm{SB})$, exchangeable aluminium $\left(\mathrm{Al}^{3+}\right)$, cation exchange capacity (CEC), total organic carbon (TOC), total nitrogen $(\mathrm{TN})$, available phosphorus $\left(\mathrm{P}_{\mathrm{a}}\right)$, and exchangeable sodium percentage (ESP).

Water sampling and analysis were carried out in shallow water $(0.2-2.9 \mathrm{~m})$ in the littoral zone of the Itaparica Reservoir,
Pernambuco. They were taken at 14 sites nearby areas of irrigation agriculture in January, April, July, and October of 2004 (CHESF, 2004). Water sampling was done by using common limnological methods. A multiparameter probe (YSI $556 \mathrm{MPS}$ ) was used for temperature, $\mathrm{pH}$, conductivity, oxygen and turbidity determination as well as a Secchi disk to measure transparency. Water chemical parameters were analyzed according to Rice et al. (2012).

\section{REsults AND Discussion}

The physical attributes of 44 selected representative soil profiles of the Itaparica Reservoir region are presented in Figures 3 and 4. Silt and clay content of the soils varies over a wide range ( $2-40 \%$ on average), but the differences between topsoil and subsoil, in general, are smaller in soils developed from the sandy cover than in the soils with more influence of fine sediments (Figure 3 and Table 1).

The fine fraction of the Arenosols (RQ), despite its low content, has a very important role in the physical properties of these soils, especially on water storage which was estimated from 3 to $7 \%$ by volume (Figure 3D). Together silt and clay fractions are responsible for most of the available water capacity of these soils (Figure 4D), besides being one of the most important criteria to differentiate RQ1, RQ2 and RQ3 soil classes (Table 1) (CHESF, 1987). Nevertheless, the maximum soil water storage is limited to about $90 \mathrm{~mm}$ to a soil depth of $150 \mathrm{~cm}$ (Figure 4A). Due to the sandy texture of the soils and excellent drainage conditions (Table 1) the average basic infiltration rate of water is very high (240-305 $\mathrm{mm} \mathrm{h}^{-1}$ ) (Soil Survey Staff, 1951) with values decreasing as the fine fraction

Table 1. Studied soils at the margins of Itaparica Reservoir

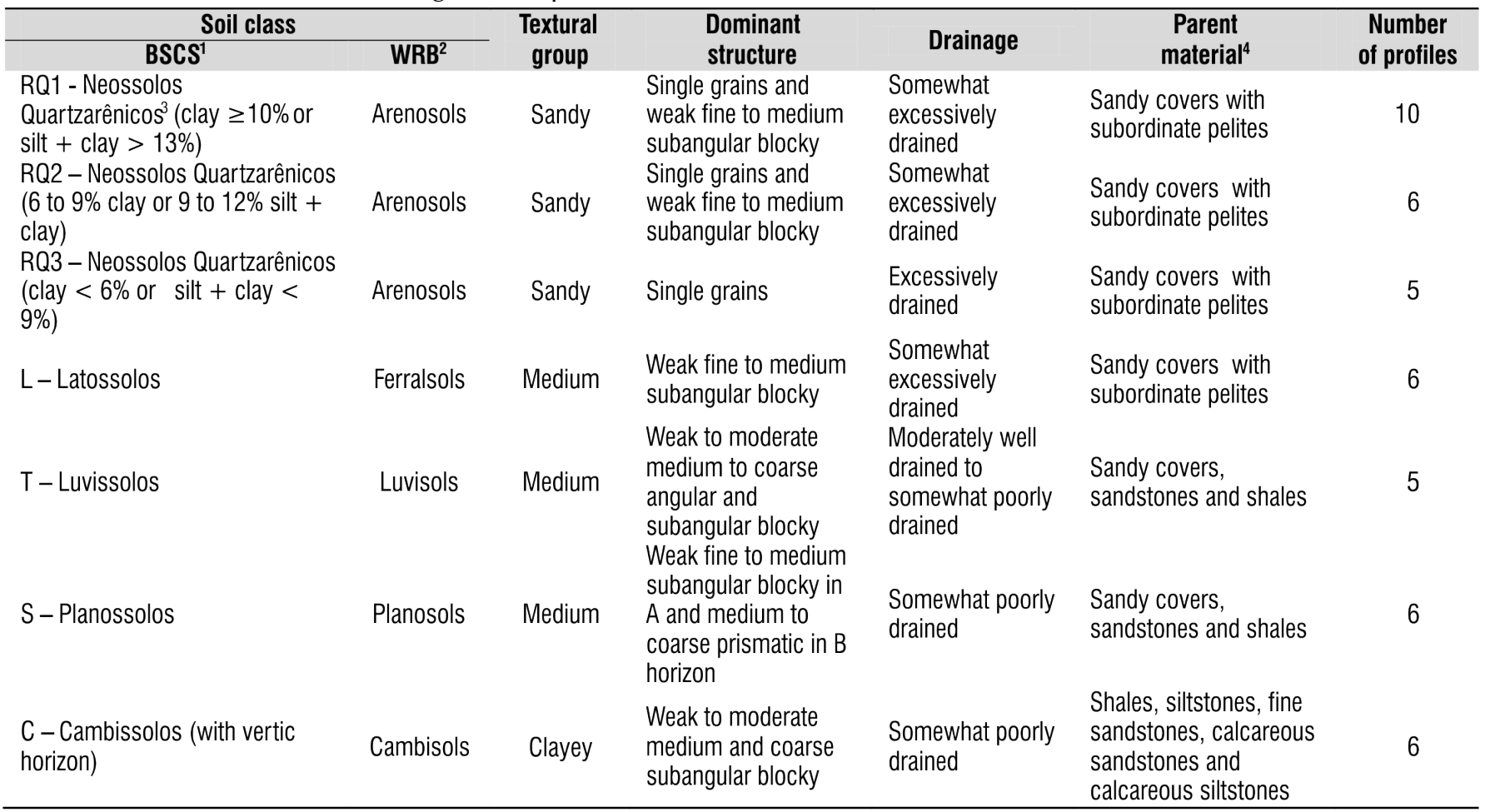

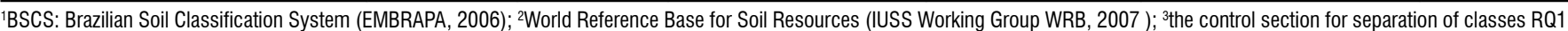
RQ2 and RQ3 as a function of clay or silt plus clay content was from 100 to $150 \mathrm{~cm}$ depth; ${ }^{4}$ data from Rocha \& Leite (1999) 
A.

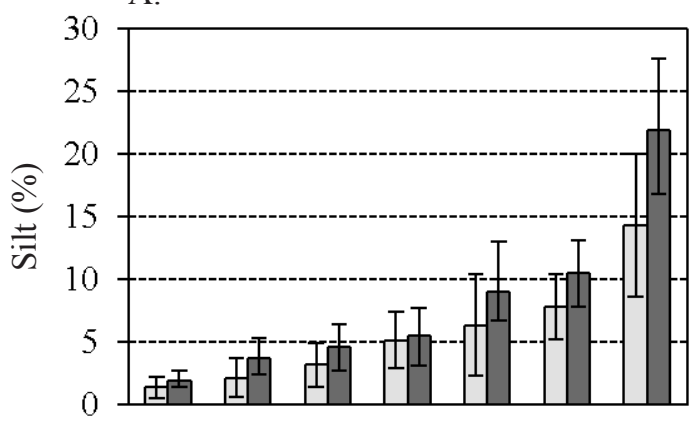

B.

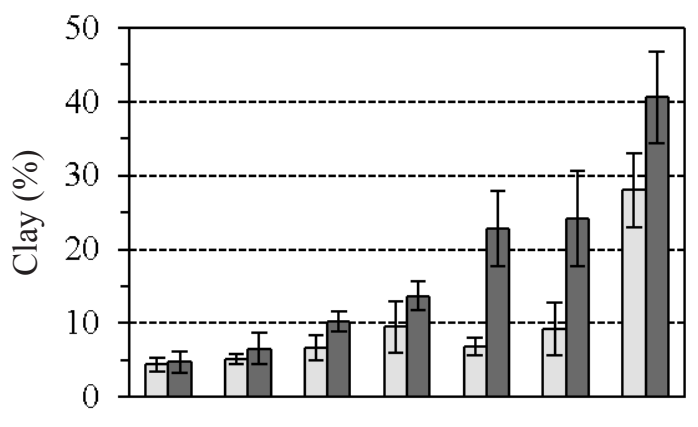

C.

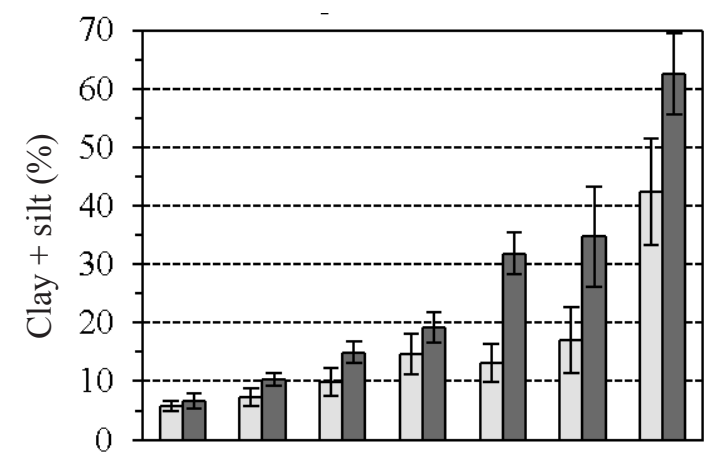

D.

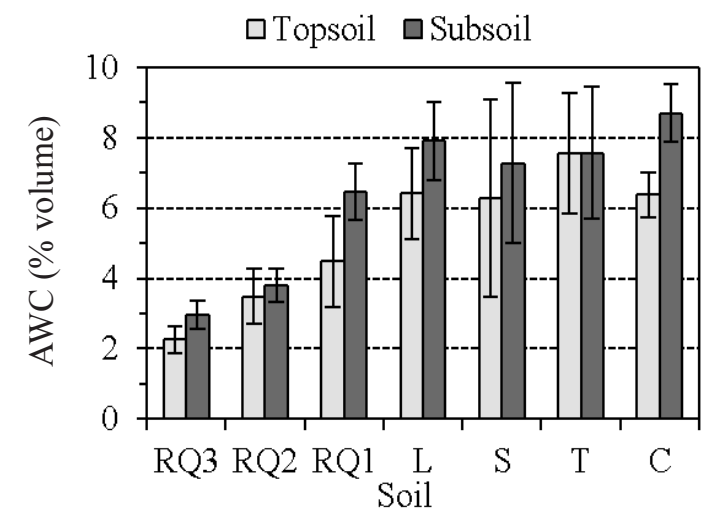

For $R Q 3, n=5 ; R Q 2, n=6 ; R Q 1, n=10 ; L, n=6 ; S, n=6 ; T, n=5$; and $C, n=6$; bars indicate \pm standard deviation. For convention see Table 1

Figure 3. Fine fraction and water storage capacity of the soils at the margins of Itaparica Reservoir. Content of silt (A), clay (B), silt plus clay (C), and available water capacity (AWC) (D)

increases (Figure 4B), but with lower values than those observed in similar soils of the region (Silva et al., 2007).

In the medium textured soils comprising the Ferralsols (L), Planosols (S) and Luvisols (T) (Table 1) available water capacity almost reached their maximum at about $8 \%$ by
A.
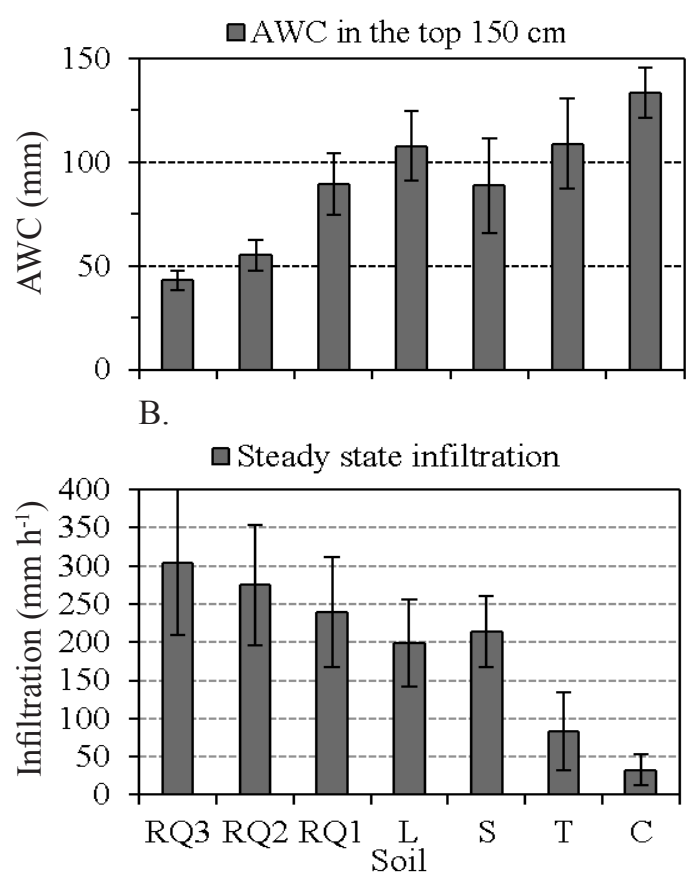

C.

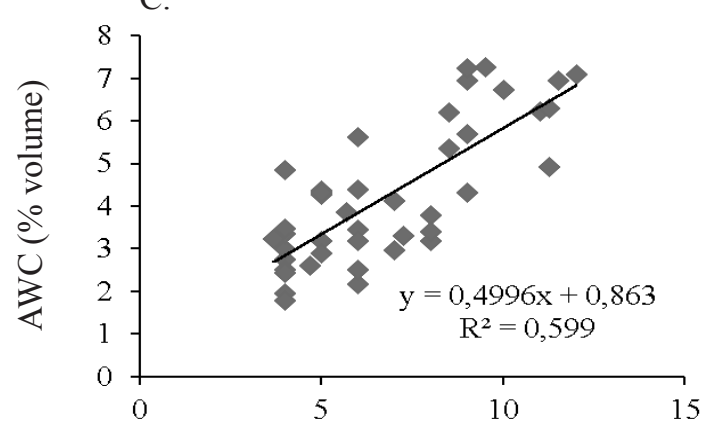

D.

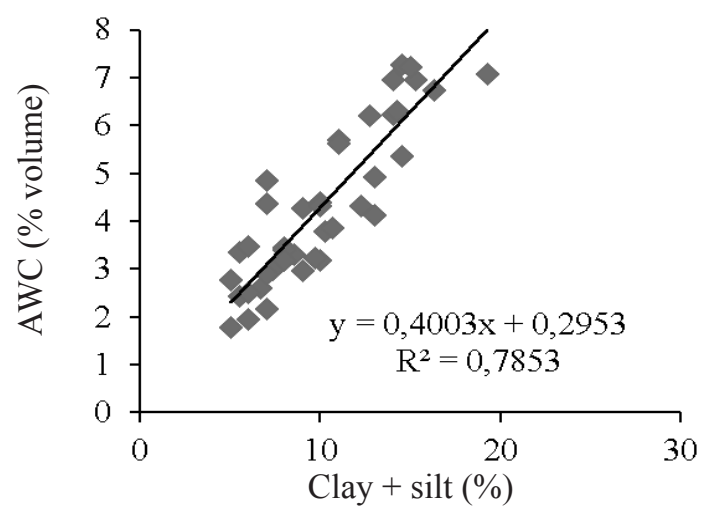

A - For RQ3, $n=5 ; R Q 2, n=6 ; R Q 1, n=10 ; L, n=6 ; S, n=6 ; T, n=5$; and $C, n=6$; $\mathrm{B}$ - For RQ3, $\mathrm{n}=8$; RQ2, $\mathrm{n}=10 ; \mathrm{RQ1}, \mathrm{n}=12 ; \mathrm{L}, \mathrm{n}=11 ; \mathrm{S}, \mathrm{n}=8 ; \mathrm{T}, \mathrm{n}=6$; and $\mathrm{C}, \mathrm{n}=$ 9; bars indicate \pm standard deviation. For convention see Table 1

Figure 4. Soil-water relationship at the margins of Itaparica Reservoir. (A) Available water capacity (AWC) for a soil depth of $150 \mathrm{~cm}$; (B) Steady ponded infiltration (double ring infiltrometer); (C) Correlation between available water capacity (AWC) and silt fraction ( $<<0.01)$, and between (D) AWC and clay plus silt fraction $(p<0.01)$ in the sandy soils

volume (Figure 3D) corresponding to about $120 \mathrm{~mm}$ for a depth of $150 \mathrm{~cm}$ (Figure 4A). The basic infiltration rate of 
water is moderate to low (Soil Survey Staff, 1951), with values decreasing from about 210 to $80 \mathrm{~mm} \mathrm{~h}^{-1}$, as the fine fraction increases (Figure 4B). Among these soils the Ferralsols have the best physical conditions. The Planosols are mainly limited by internal drainage deficiency, because they have a very compacted, practically impermeable, subsurface horizon $(\mathrm{Bt})$, which limits root growth (CHESF, 1987; EMBRAPA, 2006; Silva et al., 2007). For this reason, Planosols, in general, are very susceptible to erosion processes. However, because the horizons superjacent to Bt are relatively thick $(40-130 \mathrm{~cm})$, sandy and porous, the basic infiltration of water in Planosols of the Jatobá Basin reach about $210 \mathrm{~mm} \mathrm{~h}^{-1}$ being similar to that of the Ferralsols (Figure 4B). The Luvisols are physically limited due to both internal drainage (Table 1), reflected by low infiltration rates (Figure 4B), and high susceptibility to erosion processes, as observed by Silva et al. (2007).

The Cambisols (C) developed on fine sediments and with vertic horizon (Table 1) have several physical restrictions. They are hard to extremely hard when dry, and become very plastic and sticky when moist. Their basic infiltration rate of water reaches about $30 \mathrm{~mm} \mathrm{~h}^{-1}$ and varies from slow to moderate (Soil Survey Staff, 1951) (Figure 4B). Therefore, these soils are very susceptible to erosion processes. In natural conditions they are the most degraded soils of the region (CHESF, 1987; Silva et al., 2007). In spite of their relatively high available water capacity, about $135 \mathrm{~mm}$ for a soil depth of $150 \mathrm{~cm}$ (Figure $4 \mathrm{~A})$, there is some restriction of water use by plants due to greater resistance to root penetration in the vertic subsurface horizon. Investigations confirm that increase in resistance to root penetration decreases the availability of water to plants

A.

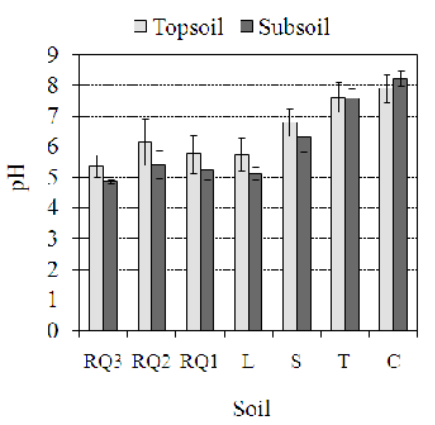

E.

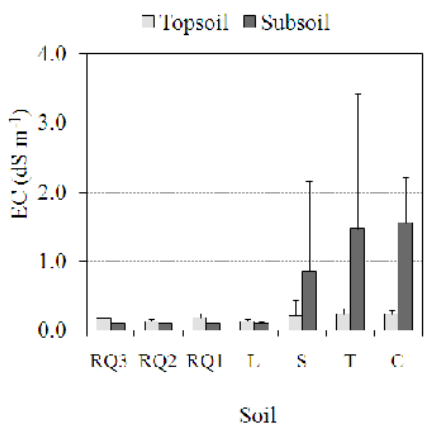

B.

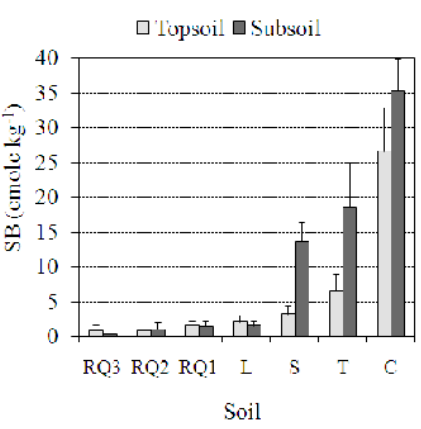

F.

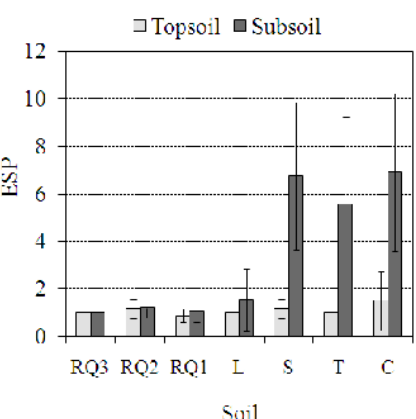

(Tormena et al., 1998). Consequently, functionalities of physical attributes of these soils are relatively unfavorable for agricultural management.

The main selected chemical attributes $(\mathrm{pH}, \mathrm{SB}$ - sum of exchangeable bases, $\mathrm{Al}^{3+}, \mathrm{CEC}, \mathrm{EC}$ - Eletrical Conductivity, and ESP - Exchangeable Sodium Percentage) clearly reflect the difference of chemical properties between the soils according to the nature of the parent material (Figure 5 and Table 1). The soils developed on sandy covers (RQ3, RQ2, RQ1 and L) are considerably desaturated of bases and emphasize the potential acidity of exchangeable aluminium with values very dispersed as it was observed in similar soils of 'Cerrado' (Brazilian savanna) (Gomes et al., 2004). Due to these characteristics, the $\mathrm{pH}$ is strongly to moderately acid (EMBRAPA, 2006) but predominantly above 5.5 in the surface horizon. This suggests that there may be no problem of aluminium toxicity for most of the crops (Sanchez et al., 2003). Concerning functionalities, these soils have very low capacity to supply nutrients to plants and hence their agricultural management is strongly dependent on the use of fertilizers.

On the contrary, the soils developed from fine sediments $(\mathrm{S}, \mathrm{T}$ and $\mathrm{C})$ reflect in their chemical attributes a richer parent material, mainly in subsurface horizons. However, despite the higher base saturation, the ESP of these soils (around 6.5\% in subsurface horizons) confers them a solodic character (EMBRAPA, 2006), apart from other soluble salts, but not enough to characterize the salic character in most of the cases (Figure 5E and F). Soils with high ESP normally exhibit unfavorable physical conditions (Qadir et al., 2006) which are commonly

C.

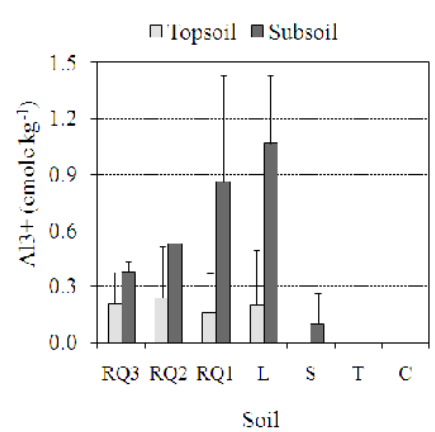

G.

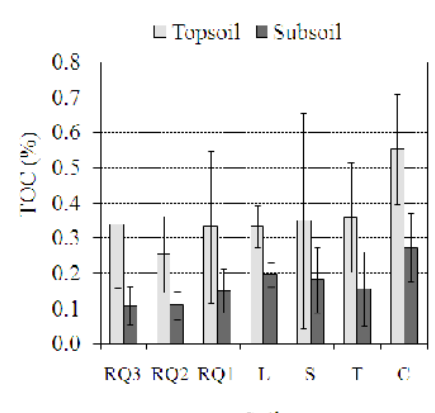

D

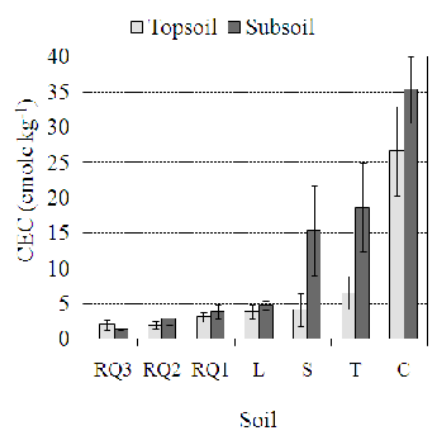

H.

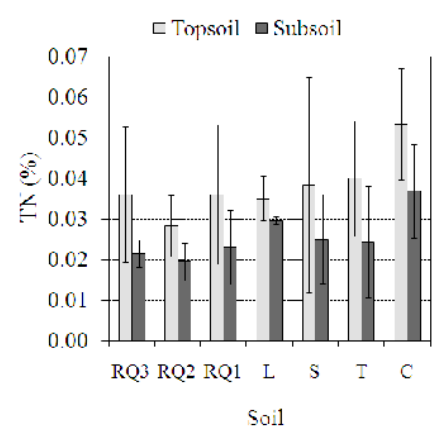

For RQ3, $n=5 ; R Q 2, n=6 ; R Q 1, n=10 ; L, n=6 ; S, n=6 ; T, n=5$; and $C, n=6$; bars indicate \pm standard deviation

Figure 5. Chemical attributes of soils at the margins of Itaparica Reservoir. (A) $p H$, (B) sum of bases (SB), (C) exchangeable aluminium $\left(\mathrm{Al}^{3+}\right)$, (D) cation exchange capacity $(\mathrm{CEC})$, (E) electrical conductivity $(\mathrm{EC})$, (F) exchangeable sodium percentage (ESP), (G) Total organic carbon (TOC) and (H) total nitrogen (TN) 
seen in Planosols (CHESF, 1987; Silva et al., 2007). The pH is neutral to moderately alkaline (Figure 5A) (EMBRAPA, 2006) as a result of the exchangeable sodium percentage (Qadir et al., 2008) and also of carbonate content, with values from 5 to $16 \%$ (CHESF, 1987). Due to the above characteristics these soils may have a nutrient imbalance or deficiency, particularly of iron and manganese (Sanchez et al., 2003; Qadir et al., 2006).

Total organic carbon and total nitrogen of the soils are shown in Figures 5G and $\mathrm{H}$. The weighted mean value of TOC in the surface horizon of representative soils of the semi-arid region of Brazil is about $0.93 \%$ (Salcedo \& Sampaio, 2008). The observed low values of TOC $(<0.60 \%)$ and TN $(<0.06 \%)$ are mainly controlled by the regional climate, apart from soil texture and fertility, which restricts production and incorporation of organic material into soils (Salcedo \& Sampaio, 2008) as was observed in the African semi-arid soils (Lufafa et al., 2008; Dossa et al., 2009). Nevertheless, a slight higher content of the TOC is perceived in the clayey soils (Figure $5 \mathrm{G}$ ), probably as a result of the association of organic matter with the fine fraction (Hassink, 1997; Eberhardt et al., 2008; McClaran et al., 2008).

The available phosphorus, although showing variations in accordance with the nature of soil parent material (Figure 6A), has no direct relation with sum of the bases or cation exchange capacity. In the soils of the sandy covers (RQ3, RQ2, RQ1 and $\mathrm{L})$, the mean values are very low $\left(<8 \mathrm{mg} \mathrm{kg}^{-1} \mathrm{P}_{\mathrm{a}}\right)$ and $\mathrm{P}_{\mathrm{a}}$ is regularly concentrated in surface horizons, but without direct relation to the TOC content (Figure 6B). Hence, it can be inferred that the surface accumulation of $\mathrm{P}_{\mathrm{a}}$ is probably due to biological recycling of plants and microorganisms. In the soils developed from fine sediments $(\mathrm{S}, \mathrm{T}$ and $\mathrm{C})$, the $\mathrm{P}_{\mathrm{a}}$ reaches the highest values (about $35 \mathrm{mg} \mathrm{kg}^{-1} \mathrm{P}_{\mathrm{a}}$ ), although showing great variation, as it is observed in the subsurface horizons of the Luvisols (T) (Figure 6A).

The distribution of $\mathrm{P}$ fractions in soils with a high content of fine materials depends on various factors. Phosphorus may precipitate with metallic ions such as $\mathrm{Al}^{3+}, \mathrm{Fe}^{3+}$ and $\mathrm{Ca}^{2+}$, and it may also associate with the organic fractions (Delgado \&
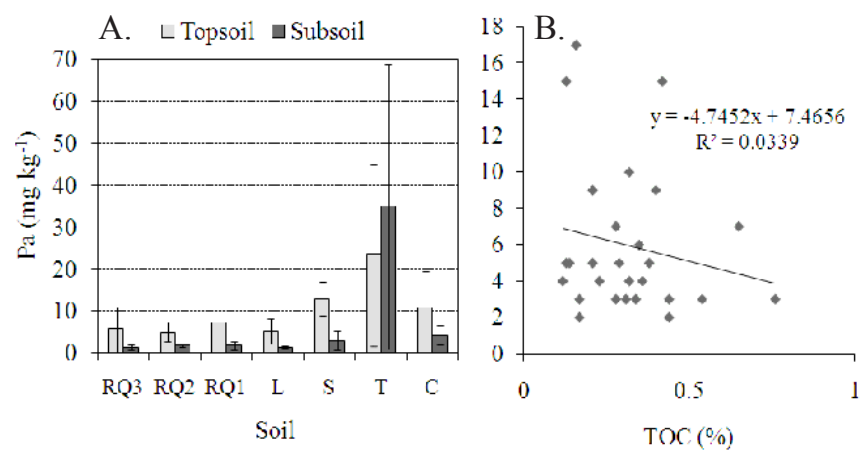

For $\mathrm{RQ3}, \mathrm{n}=5 ; \mathrm{RQ2}, \mathrm{n}=6$; $\mathrm{RQ1}, \mathrm{n}=10 ; \mathrm{L}, \mathrm{n}=6 ; \mathrm{S}, \mathrm{n}=6 ; \mathrm{T}, \mathrm{n}=5$; and $\mathrm{C}, \mathrm{n}=6$; bars indicate \pm standard deviation

Figure 6. (A) Available phosphorus $\left(\mathrm{P}_{\mathrm{a}}\right)$ in soils at the margins of Itaparica Reservoir; (B) Correlation of $\mathrm{P}_{\mathrm{a}}$ with total organic carbon (TOC) $(p>0.05)$ in surface horizons of the soils developed from sandy covers ( $R Q$ and $\mathrm{L} ; \mathrm{n}=27$ )

Scalenghe, 2008; Eberhardt et al., 2008). In Luvisols of the semi-arid region of Pernambuco State (Brazil), the highest concentration of $\mathrm{P}$ was observed in the inorganic phases (Araújo et al., 2004). However, for an understanding of the global cycle of $\mathrm{P}$ comprising soils and aquatic systems, more research is needed (Delgado \& Scalenghe, 2008).

The data in Table 2 summarize information of the water quality parameters of Itaparica Reservoir in the littoral zone. Water is normally poor in dissolved ions, nitrogen compounds, soluble reactive phosphorus (SRP), and total phosphorus. In aquatic systems mainly nitrogen and phosphorus are responsible for considerable algae growth that indicates the process of eutrophication (Delgado \& Scalenghe, 2008; Granéli et al., 2008; Sperling et al., 2008; Fragoso Jr. et al., 2011). A strong correlation exists between available phosphorus and chlorophyll-a (Chl-a) concentrations (Canfield Jr. et al., 1985) and, therefore, Chl-a can be used as a parameter to indicate the trophic level. The OECD classification of Vollenweider \& Kerekes (1982) considers that in the eutrophic state the

Table 2. Water quality parameters in the littoral zone of Itaparica Reservoir (CHESF, 2004)

\begin{tabular}{|c|c|c|c|c|}
\hline \multirow{2}{*}{ Parameter (1) } & \multicolumn{4}{|c|}{ Sampling in 2004 ${ }^{(2)}$} \\
\hline & January & April & July & October \\
\hline Temperature $\left({ }^{\circ} \mathrm{C}\right)$ & $28.6(s d=1.0)$ & $25.2(\mathrm{sd}=1.5)$ & $24.5(s d=0.4)$ & $27.7(\mathrm{sd}=0.7)$ \\
\hline Secchi Depth (m) & $1.1(\mathrm{sd}=1.1)$ & $0.2(\mathrm{sd}=0.1)$ & $1.4(\mathrm{sd}=0.2)$ & $2.9(\mathrm{sd}=1.0)$ \\
\hline Conductivity $\left(\mu \mathrm{S} \mathrm{cm}^{-1}\right)$ & $97(s d=36)$ & $129(\mathrm{sd}=15)$ & $72(s d=3)$ & $76(s d=3)$ \\
\hline $\mathrm{pH}(\min .-\max )$. & $7.2-8.0$ & $7.6-9.4$ & $7.1-7.7$ & $7.1-7.6$ \\
\hline Turbidity (mg L-1 & $64(s d=25)$ & $84(s d=10)$ & $47(s d=2)$ & $49(s d=2)$ \\
\hline Suspended material $\left(\mathrm{mg} \mathrm{L}^{-1}\right)$ & $52(s d=49)$ & $33(s d=11)$ & $10(s d=5)$ & $10(s d=5)$ \\
\hline Alkalinity $\left(\mathrm{mg} \mathrm{L}^{-1} \mathrm{CaCO}_{3}\right)$ & $29(\mathrm{sd}=3)$ & $36(s d=4)$ & $25(s d=1)$ & $33(s d=1)$ \\
\hline $\mathrm{O}_{2}\left(\mathrm{mg} \mathrm{L}^{-1}\right)(\min .-\max )$. & $7.3-12.0$ & $5.5-8.8$ & $6.0-7.0$ & $5.8-7.9$ \\
\hline $\mathrm{O}_{2}(\%)$ (min. $\left.-\max .\right)$ & $93-150$ & $70-120$ & $72-84$ & $76-98$ \\
\hline $\mathrm{NH}_{4}-\mathrm{N}\left(\mu \mathrm{g} \mathrm{L}^{-1}\right)$ & $0.4(s d=0.4)$ & $1.0(\mathrm{sd}=1.2)$ & $0.8(s d=0.7)$ & $0.3(s d=0.3)$ \\
\hline $\mathrm{NO}_{2}-\mathrm{N}\left(\mu \mathrm{g} \mathrm{L}^{-1}\right)$ & $0.7(\mathrm{sd}=1.0)$ & $0.4(s d=0.3)$ & $0.1(s d=0.1)$ & $0.3(s d=0.1)$ \\
\hline $\mathrm{NO}_{3}-\mathrm{N}\left(\mu \mathrm{g} \mathrm{L}^{-1}\right)$ & $28(s d=32)$ & $54(s d=31)$ & $14(s d=14)$ & $2.1(s d=1.1)$ \\
\hline $\mathrm{N}_{\text {total }}\left(\mu \mathrm{g} \mathrm{L}^{-1}\right)$ & $198(\mathrm{sd}=81)$ & $629(\mathrm{sd}=182)$ & $270(\mathrm{sd}=57)$ & $236(\mathrm{sd}=81)$ \\
\hline $\operatorname{SRP}\left(\mu \mathrm{g} \mathrm{L}^{-1}\right)$ & $1.4(\mathrm{sd}=1.9)$ & $1.5(\mathrm{sd}=1.9)$ & $0.7(s d=0.5)$ & $0.7(\mathrm{sd}=0.4)$ \\
\hline $\mathrm{P}_{\text {total }}\left(\mu \mathrm{g} \mathrm{L}^{-1}\right)$ & $15(s d=7)$ & $42(s d=34)$ & $11(s d=5)$ & $13(s d=3)$ \\
\hline $\mathrm{N} / \mathrm{P}$ & $18(\mathrm{sd}=15)$ & $22(s d=12)$ & $27(s d=12)$ & $19(\mathrm{sd}=6)$ \\
\hline Chlorophyll-a ( $\left.\mu \mathrm{g} \mathrm{L}^{-1}\right)$ (min. - max.) & $14.6(3.1-56.5)$ & $19(6.6-44.0)$ & $19(2.0-60.5)$ & nd \\
\hline Total Coliform (cfu $100 \mathrm{~mL}^{-1}$ ) & $<1,600-1,600$ & $500-11,000$ & $140-3,000$ & $80-1,700$ \\
\hline Fecal Coliform (cfu $100 \mathrm{~mL}^{-1}$ ) & $<1,600-3,000$ & $8-2,300$ & $7-500$ & $0-300$ \\
\hline
\end{tabular}

(1) Data set $(n=14)$ except for coli $(n=5)$; (2)sd = standard deviation; SRP = soluble reactive phosphorus; and $n d=$ no data available 
mean concentration of Chl-a varies from 8 to $25 \mu \mathrm{g} \mathrm{L}^{-1}$ and the maximum, from 25 to $75 \mu \mathrm{g} \mathrm{L} \mathrm{L}^{-1}$. In Itaparica Reservoir margins, the Chl-a concentration, especially the maximum values about $60 \mu \mathrm{g} \mathrm{L}^{-1}$ (Table 2), point out that the water is under eutrophication process.

The eutrophication processes of the waters in Itaparica Reservoir have their origin in both natural and anthropogenic causes. Natural eutrophication is given by the export of nutrients from the watershed carried by drainage waters of rivers and creeks as well as by run off and wash out by intensive rainfall. For this reason, major impact on water quality occurs in the rainy season, notably from January to April (Table 2).

In the crystalline areas surrounding the reservoir, rivers and seasonal creeks drain large areas with soils rich in nutrients, mainly Luvisols and Planosols with vertic horizons (Brasil, 1973). The available phosphorus content of these soils is highly variable, but commonly with values from 10 to $400 \mathrm{mg} \mathrm{kg}^{-1}$ (Brasil, 1973; Araújo et al., 2004). Moreover, it is important to take into account the release of nutrient from rich submerged soils mainly in the margin of the Reservoir. Large areas with vertic soils, as well as soils developed from alluvional sediments were submerged by damming up and serve as a long time source of eutrophication. The content of available phosphorus of these soils normally varies between 10 to $300 \mathrm{mg} \mathrm{kg}^{-1}$ (Brasil, 1973; CHESF, 1987).

Besides natural causes (Lloret et al., 2008; Chellappa et al., 2009; Fragoso Jr. et al., 2011; Palácio et al., 2011), anthropogenic factors for reservoir eutrophication are numerous. It includes contamination by nutrients and pollutants resulting from agricultural and cattle raising activities, non-treated effluents of urban areas, and aquaculture systems (Hadas et al., 1999; Brainwood et al., 2004; Ma et al., 2009; Strauch et al., 2009; Kang et al., 2010; Moreno-Mateosa et al., 2010).

Eutrophication of surface waters (Table 2) causes environmental problems and impact on water quality for human consumption, livestock and irrigated agriculture (Granéli et al., 2008; Strauch et al., 2009). Contaminants like fecal bacteria (Escherichia coli), intestinal parasites (Giardia intestinalis, Cryptosporidium parvum) and cyanotoxins (e. g. microcystin, saxitoxin, and cylindrospermopsin) emitted by cyanobacteria (blue-green algae) can impact humans and livestock. The insufficient wastewater treatment leads to a high number of coliform bacteria (E. coli) and of intestinal parasites in the reservoir water, mainly in the littoral zone with shallow water and a reduced dilution of the inflow (Table 2). Data about the occurrence of Giardia and Cryptosporidium are scarce due to analytical problems. Nevertheless, the maximum tolerable concentrations of these parasites in drinking water are very low, varying from zero to $10^{-5}$ individuals $\mathrm{L}^{-1}$ (VROM, 2001) and with regard to $E$. coli, zero colony forming units per $100 \mathrm{~mL}$ are given by the World Health Organization (WHO, 2004). These quality parameters for drinking water must be applied for water used in agriculture and for irrigation of fruits and vegetables, if no more specific limit concentrations are developed.

High nutrient concentration, usually phosphorus together with nitrogen, so that $\mathrm{N} / \mathrm{P}<16$ promotes the occurrence of cyanobacteria (Granéli et al., 2008) which sometimes reaches large amounts in Itaparica Reservoir (CHESF, 2004).
Cyanotoxins are toxic for humans and livestock and their accumulation at least in some plants is proved (Falconer \& Humpage, 2005; Peuthert et al., 2007; Crush et al., 2008).

\section{Conclusions}

1. The functionalities of selected physical and chemical attributes of soils in the surrounding area of Itaparica Reservoir in the Jatobá Basin are closely related to the parent material, with exception of carbon and nitrogen contents linked to the nature of the organic matter in semi-arid conditions.

2. The low capacity to retain and supply nutrients and the high permeability were the striking characteristics of the soils developed from sandy covers, which comprise Arenosols and Ferralsols. On the other hand, the higher nutrient availability, presence of salts, and permeability restrictions are the outstanding features of the soils developed from materials with larger influence of fine sediments, namely Cambisols, Luvisols and Planosols.

3. In addition to anthropogenic causes, there are natural causes that contribute to the eutrophication process of the Itaparica Reservoir waters, especially phosphorus enrichment. However, additional research is necessary to quantify the different sources of nutrients.

4. The results also suggested that insufficient wastewater treatment has contributed to contamination and proliferation of pathogenic bacteria in surface waters of Itaparica Reservoir.

\section{AcKnowledgments}

This study was supported by the PROBRAL Program of Capes/Brazil (Coordenação de aperfeiçoamento de Pessoal de Nível Superior) and DAAD/Germany (German Academic Exchange Service). The authors thank Companhia Hidro Elétrica do São Francisco for making information available to this study. We are also grateful to Paulo Cardoso de Lima for his suggestions and mainly for translating this text into English.

\section{Literature Cited}

Araújo, M. S. B.; Schaefer, C. E. R.; Sampaio, E. V. S. B. Soil phosphorus fractions from toposequences of semi-arid Latosols and Luvisols in northeastern Brazil. Geoderma, v.119, p.309-321, 2004.

Brainwood, M. A.; Burgin, S.; Maheshwari, B. Temporal variations in water quality of farm dams: impacts of land use and water sources. Agricultural Water Management, v.70, p.151-175, 2004.

Brasil. Ministério da Agricultura. Departamento Nacional de Pesquisa Agropecuária. Divisão de Pesquisa Pedológica. Levantamento exploratório-reconhecimento de solos do Estado de Pernambuco. Recife: DNPEA, 1973. 2v. Boletim Técnico, 26; SUDENE. DRN. Série Pedologia, 14.

Canfield Jr. D. E.; Linda, S. B.; Hodgson, L. M. Chlorophyllbiomass-nutrient relationships for natural assemblages of florida phytoplankton. Water Resources Bulletin, v.21, p.381-391, 1985. 
Chellappa, N. T.; Chellappa, T.; Câmara, F. R. A.; Rocha, O.; Chellappa, S. Impact of stress and disturbance factors on the phytoplankton communities in Northeastern Brazil reservoir. Limnologica, v.39, p.273-282, 2009.

CHESF - Companhia Hidro Elétrica do São Francisco. Projeto de ocupação da borda do lago de Itaparica, margem esquerda. Relatório de pedologia. Recife: CHESF, Tomos 1-3, 1987. 695p. Relatório Técnico THEMAG Engenharia/CHESF.

CHESF - Companhia Hidro Elétrica do São Francisco. Programa de monitoramento limnológico e avaliação da qualidade da agua do reservatório de Itaparica. Recife: PETCON, 2004. $77 \mathrm{p}$.

Corrêa, R. M.; Freire, M. B. G. S.; Ferreira, R. L. C.; Silva, J. A. A.; Pessoa, L. G.M.; Miranda, M. A.; Melo, D. V. M. Atributos físicos de solos sob diferentes usos com irrigação no semiárido de Pernambuco. Revista Brasileira de Engenharia Agrícola e Ambiental, v.14, p.358-365, 2010.

Crush, J. R.; Briggs, L. R.; Sprosen, J. M.; Nichols, S. N. Effect of irrigation with lake water containing microcystins on microcystin content and growth of ryegrass, clover, rape, and lettuce. Environmental Toxicology, v.23, p.246-252, 2008.

Delgado, A.; Scalenghe, R. Aspects of phosphorus transfer from soils in Europe. Journal of Plant Nutrition and Soil Science, v.171, p.552-575, 2008.

Dossa, E. L.; Khouma, M.; Diedhiou, I.; Sene, M.; Kizito, F.; Badiane, A.N.; Samba, S.A.N.; Dick, R.P. Carbon, nitrogen and phosphorus mineralization potential of semiarid Sahelian soils amended with native shrub residues. Geoderma, v.148, p.251-260, 2009.

Eberhardt, D. N.; Vendrame, P. R. S.; Becquer, T.; Guimarães, M. F. Influência da granulometria e da mineralogia sobre a retenção do fósforo em Latossolos sob pastagens no cerrado. Revista Brasileira de Ciência do Solo, v.32, p.1009-1016, 2008.

EMBRAPA - Empresa Brasileira de Pesquisa Agropecuária. Centro Nacional de Pesquisa de Solos. Manual de métodos de análise de solos, 2.ed. Rio de Janeiro: Embrapa Solos, 1997. 212p.

EMBRAPA - Empresa Brasileira de Pesquisa Agropecuária. Centro Nacional de Pesquisa de Solos. Sistema brasileiro de classificação de solos, 2.ed. Rio de Janeiro: Embrapa Solos, 2006. 306p.

Falconer, I. R.; Humpage, A. R. Health risk assessment of cyanobacterial (blue-green algal) toxins in drinking water. International Journal of Environmental Research and Public Health, v.2, p.43-50, 2005.

Fragoso Jr. C. R.; Marques, D. M. L.; Ferreira, T. F.; Jan H. Janse; van Nes, E. H. Potential effects of climate change and eutrophication on a large subtropical shallow lake. Environmental Modelling \& Software, v.26, p.1337-1348, 2011.

Gomes, J. B. V.; Curi, N.; Motta, P. E. F.; Ker, J. C; Marques, J. J. G. S. M.; Schulze, D.G. Análise de componentes principais de atributos físicos, químicos e mineralógicos de solos do bioma cerrado. Revista Brasileira de Ciência do Solo, v.28, p.137-153, 2004.
Granéli, E.; Weberg, M; Salomon, P. S. Harmful algal blooms of allelopathic microalgal species: The role of eutrophication. Harmful Algae, v.8, p.94-102, 2008.

Hadas, A.; Hadas, A.; Sagiv, B.; Haruvy, N. Agricultural practices, soil fertility management modes and resultant nitrogen leaching rates under semi-arid conditions. Agricultural Water Management, v.42, p.81-95, 1999.

Hassink, J. The capacity of soils to preserve organic $\mathrm{C}$ and $\mathrm{N}$ by their association with clay and silt particles. Plant Soil, v.191, p.77-87, 1997.

IUSS Working Group WRB. World reference base for soil resources 2006, first update 2007. World soil resources reports No. 103. Rome: FAO, 2007. 216p.

Kang, J. H.; Lee, S. W.; Cho, K. H.; Ki, S. J.; Cha, S. M.; Kim, J. H. Linking land-use type and stream water quality using spatial data of fecal indicator bacteria and heavy metals in the Yeongsan river basin. Water Research, v.44, p.41434157, 2010.

Lloret, J.; Marín, A.; Marín-Guirao, L. Is coastal lagoon eutrophication likely to be aggravated by global climate change? Estuarine, Coastal and Shelf Science, v.78, p.403412, 2008.

Lufafa, A.; Diédhiou, I.; Samba, S. A. N.; Séné, M.; Khouma, M.; Kizito, F.; Dick, R. P.; Dossa, E.; Noller, J. S. Carbon stocks and patterns in native shrub communities of Senegal's Peanut Basin. Geoderma, v.146, p.75-82, 2008.

Ma J.; Ding, Z.; Wei, G.; Zhao, H.; Huang, T. Sources of water pollution and evolution of water quality in the Wuwei basin of Shiyang river, Northwest China. Journal of Environmental Management, v. 90, p.1168-1177, 2009.

McClaran, M. P.; Moore-Kucera, J.; Martens, D. A.; Haren, J. V.; Marsh, S. E. Soil carbon and nitrogen in relation to shrub size and death in a semi-arid grassland. Geoderma, v.145, p.60-68, 2008.

Moreno-Mateosa, D.; Pedrocchib, C.; Comín, F. A. Effects of wetland construction on water quality in a semiarid catchment degraded by intensive agricultural use. Ecological Engineering. v.36, p.631-639, 2010.

Palácio, H. A. Q.; Araújo Neto, J. R.; Meireles, A. C. M.; Andrade E. M.; Santos, J. C. N.; Chaves, L. C. G. Similaridade e fatores determinantes na salinidade das águas superficiais do Ceará, por técnicas multivariadas. Revista Brasileira de Engenharia Agrícola e Ambiental. v.15, p.395-402, 2011.

Peuthert, A.; Chakrabarti, S.; Pflugmacher, S. Uptake of microc ystins-LR and -LF (cyanobacterial toxins) in seedlings of several important agricultural plant species and the correlation with cellular damage (lipid peroxidation). Environmental Toxicology, v.22, p.436-442, 2007.

Qadir, M.; Noble, A. D.; Schubert, S.; Thomas, R. J.; Arslan, A. Sodicity induced land degradation and its sustainable management: Problems and prospects. Land Degradation \& Development, v.17, p.661-676, 2006.

Qadir, M.; Qureshi, A. S.; Cheraghi, S. A. M. Extent and characterization of salt-affected soils in Iran and strategies for their amelioration and management. Land Degradation \& Development, v.19, p.214-227, 2008. 
Rice, E. W.; Baird, R. B.; Eaton, A. D.; Clesceri, L. S. (ed.). Standards methods for the examination of water and wastewater. 22.ed. Washigton: American Public Health Association, 2012. 1.496p.

Rocha, D. E. G. A.; Leite, J. F. Estudo hidrogeológico da Bacia do Jatobá - PE. Recife: CPRM, 1999. 20p. Série Hidrogeologia. Estudos e Projetos, 2.

Sahrawat, K. L.; Wani, S. P.; Pathak, P.; Rego, T. J. Managing natural resources of watersheds in the semi-arid tropics for improved soil and water quality: A review. Agricultural Water Management, v.97, p.375-381, 2010.

Salcedo, I. H.; Sampaio, E. V. S. B. Matéria orgânica do solo no bioma Caatinga. In: Santos, G. A.; Silva, L. S.; Cannelas, L. P.; Camargo, F. A. O. (ed.) Fundamentos da matéria orgânica do solo: Ecossistemas tropicais e subtropicais. 2.ed. Porto Alegre: Metrópole, 2008. Cap. 22, p.419-441.

Sanchez, P. A.; Palm, C. A.; Buol, S. W. Fertility capability soil classification: a tool to help assess soil quality in the tropics. Geoderma, v.114, p.157-185, 2003.

Silva, F. H. B. B.; Luz, L. R. Q. P.; Araújo Filho, J. C.; Santos, J. C. P. (ed.). Avaliação detalhada do potencial de terras para irrigação nas áreas de reassentamento de colonos do projeto Barreiras - Bloco 2, Tacaratu, PE. Rio de Janeiro: Embrapa Solos, 2007. 153p.
Soil Survey Staff. Soil survey manual. Washington: USDA., U. S. Government Printing Office, 1951. 503p. Agriculture handbook, 18.

Sperling, E. von; Ferreira, A. C. S.; Gomes, L. N. L. Comparative eutrophication development in two Brazilian water supply reservoirs with respect to nutrient concentrations and bacteria growth. Desalination, v.226, p.169-174, 2008.

Strauch, A. M.; Kapust, A. R.; Jost, C. C. Impact of livestock management on water quality and streambank structure in a semi-arid, African ecosystem. Journal of Arid Environments, v.73, p.795-803, 2009.

Tormena, C. A.; Silva, A. P.; Libardi, P. L. Caracterização do intervalo hídrico ótimo de um latossolo roxo sob plantio direto. Revista Brasileira de Ciência do Solo, v.22, p.573$581,1998$.

Vollenweider, R. A.; Kerekes, J. Eutrophication of waters: Monitoring, assessment, and control. Paris: OECD, 1982. $154 \mathrm{p}$.

VROM. Waterleidingbesluit (Drinking Water Decree). Ministry of housing, Physical planning and the environment. The Hague: The Netherlands, 2001.

WHO - World Health Organization. Guidelines for drinkingwater quality. 3.ed. Geneva: World Health Organization, v.1, 2004. 515p. 